\title{
Uplatnění fenomenografického přístupu na příkladu výzkumu využívání digitálních technologií ve vzdělávání ${ }^{1}$
}

\author{
Hana Staudková \\ Masarykova univerzita, Filozofická fakulta, Ústav pedagogických věd \\ Redakci zasláno 13. 2. 2016 / upravená verze obdržena 11. 7. 2016 / \\ k uveřejnění přijato 17. 8. 2016
}

\begin{abstract}
Abstrakt: Příspěvek se věnuje možnostem využití fenomenografie v pedagogickém výzkumu na příkladu výzkumu digitálních technologií ve vzdělávání. Tato výzkumná orientace je $\mathrm{v}$ českém prostředí téměř neznámá a hlavním cílem příspěvku je otevřít diskusi o možnostech jejího využití. V první části je podán základní přehled o principech fenomenografie. Dále se článek zaměřuje na otázku vztahu fenomenografie a fenomenologie a představuje je jako samostatné přístupy, z nichž každý má odlišné zaměření, cíle a výsledky. Konkrétní fenomenograficko-metodologické postupy jsou konfrontovány s designem zakotvené teorie; příspěvek popisuje jejich základní odlišnosti i společné prvky. Možnosti využití tohoto přístupu jsou doloženy na konkrétních příkladech výzkumů týkajících se digitálních technologií ve vzdělávání a závěrem jsou diskutovány jeho přednosti i slabiny. Ukazuje se, že tato výzkumná koncepce v sobě nese velký a dosud nevyužitý potenciál pro český pedagogický výzkum, především pro výzkum ve vysokoškolském prostředí, kterému je „šita na míru“.
\end{abstract}

Klíčová slova: fenomenografie, výzkum vysokého školství, digitální technologie ve vzdělávání

Příspěvek se věnuje možnostem využití fenomenografie v pedagogickém výzkumu na příkladu zkoumání oblasti digitálních technologií ve vzdělávání. Fenomenografie je v zahraničním výzkumu týkajícím se učení poměrně známý přístup, $\mathrm{v}$ českém pedagogickém výzkumu však dlouhodobě opomíjený. A to i přesto, že jde o výzkumnou perspektivu s dlouhou tradicí a prověřenou výsledky (srov. např. Marton, Dall'Alba, \& Beaty, 1993; Prosser, Trigwell, \& Taylor, 1994; Vermunt, 1996).

1 Tento článek vznikl v rámci projektu Celoživotní učení v institucionálních souvislostech (MUNI/A/1147/2015). 
Vzhledem k tomu, že cílem není podat souhrnný ucelený výklad, ale spíše představit základní principy fenomenografie, je článek strukturován schematicky do šesti kapitol. Nikoliv náhodou připomínají jejich názvy a témata prvky paradigmatického modelu zakotvené teorie. Ta má s fenomenografickým výzkumem mnoho společného, jejich vztah je jednou z otázek, kterým se článek věnuje. Úvodem je definován ústřední jev, tedy fenomenografie, která je představena jako samostatný specifický výzkumný př́stup. Dále text popisuje kořeny jejího vzniku a související kontext. Zaměřuje se na charakteristiky fenomenografie a intervenující podmínky, jež vedou ke konkrétním strategiím jednání, tedy realizovaným fenomenografickým výzkumům. Závěrem jsou formulovány výzvy pro český pedagogický výzkum.

\section{Fenomén fenomenografie}

Slovo fenomenografie pochází z řeckého phainomenon (vzhled, zdání) a graphein (psát). Termín se poprvé objevil pravděpodobně v práci Sonnemana (1954, cit. podle Dahlin, 2007), jenž jej použil pro odlišení Jaspersova psychopatologického výzkumu od fenomenografie v pojetí Martina Heideggera (Dahlin, 2007). Později Marton (1981) termín využil k označení nového směru pedagogického výzkumu, jehož cílem je pochopení kvalitativně rozdílného prožívání zkušenosti a který zodpovídá otázky týkající se myšlení a učení. Tato výzkumná koncepce se rozvíjela především ve výzkumu př́stupů $k$ učení na univerzitě ve švédském Göteborgu v pracích Ference Martona a jeho kolegů, a to již několik let před tím, než byla pojmenována jako svébytný výzkumný design. Fenomenografie bývá označována mnoha různými způsoby: př́stup $k$ výzkumu, metoda, orientace, paradigma, perspektiva či výzkumný program (Tight, 2015). Marton a Boothová (1997) nepovažují fenomenografii za metodu samu o sobě, jde podle nich o celkový př́ístup se silným pedagogickovýzkumným zájmem. Každopádně z metodologického hlediska stanovili velmi specifické a normativní postupy provádění tohoto typu výzkumu.

Fenomenografie je definována jako „specifický výzkum, který se zaměřuje na kvalitativně odlišné způsoby, jimiž lidé prožívají zkušenosti, uvažují, vnímají a rozumí různým aspektům světa kolem sebe" (Marton, 1986, s. 31). Zaměřuje se na popis, analýzu a pochopení zkušenosti a jejím hlavním cílem je zachytit odlišnosti v jejím prožívání. Lze identifikovat tři linie tematického vývoje fenomenografického výzkumu. První se soustředí na obecné aspekty učení, především na kvalitativní rozdíly v přístupu k učení a jeho výstupům. 
Druhá linie výzkumu se zaměřuje na učení a pojetí učení studentů uvnitř kontextu dané disciplíny. Třetí rovina se týká výzkumů každodennosti a individuálních představ ohledně různých aspektů života (Marton, 1986).

Podle Tighta (2015) je fenomenografie pravděpodobně jediný výzkum, jenž vzniknul v prostředí vysokoškolského vzdělávání a byl vytvořen přímo výzkumníky, kteří se vysokoškolskému vzdělávání primárně věnují. Pro zkoumání výuky a studia ho však využívá pouze velmi malé procento výzkumníků (Tight, 2015).

\section{Perspektiva druhého řádu jako základní výzkumný kontext}

Marton (1981) se vymezil proti výzkumným přístupům, které se učení studentů věnují „zvnějšku“ a nerozlišují specifika učícího se a jeho individuální vnímání. Fenomenografie se nesoustředí na individuální charakteristiky učícího se ani na motivaci (typické pro psychologické přístupy k učení) ani na rod, etnicitu nebo tř́́du (typické pro sociálněvědní př́stupy ke studiu vysokého školství). Namísto toho sleduje, jak studující rozumí tomu, co vlastně znamená učit se a naučit se (Pabian, 2012, s. 61). Tuto perspektivu, jež sleduje zkušenost tak, jak ji prožívá samotný respondent, označuje Marton (1981) jako perspektivu druhého řádu (angl. second-order perspective). Fenomenografický výzkum se nesoustředí na fenomén jako takový, ale na rozdílné způsoby, jimiž jej lidé chápou a prožívají. ${ }^{2}$

Předmětem fenomenografického výzkumu je subjektivní prožívání a snaha o jeho pochopení v rámci celku. Podle Martona (2000, cit. podle Yates, Partridge, \& Bruce, 2012) objekt a subjekt nejsou odděleni a na sobě nezávislí, jde o tzv. nedualistickou ontologickou perspektivu. Neexistují dva světy; reálný a objektivní svět na jedné straně, na druhé straně subjektivní svět. Existuje pouze jeden svět, který je zažíván a chápán různými způsoby. Je zároveň subjektivní i objektivní (Yates et al., 2012). Nedualistická definice zkušenosti je podstatným aspektem fenomenografie (Linder \& Marshall, 2003) a je základem perspektivy druhého řádu. Zkušenost je zde charakterizována jako vnitřní vztah mezi jednotlivcem a fenoménem (Linder \& Marshall, 2003).

To můžeme dokreslit př́íkladem z výzkumu týkajícího se vyhledávání informací na internetu. Otázka z perspektivy prvního řádu by zněla: „Proč lidé vyhledávají informace na webu?“ Otázka druhého řádu pak: „Jakým způsobem lidé vyhledávají informace na webu?“ (Yates et al., 2012). 
Hlavní tematickou linií fenomenografického výzkumu je zkušenost učení. Fenomenografický výzkum se nesoustředí na učení samo o sobě, ale sleduje vztah mezi jedincem a učením a umožňuje zachytit rozdílné způsoby prožívání tohoto vztahu. Zkušenost učení zahrnuje studentův př́stup $k$ učení a pojetí učení. Rozlišení hloubkových a povrchových přístupů k učení je považováno za vlivný směr výzkumu vzdělávání ve vysokém školství, jehož přínos spočívá mimo jiné v důrazu na myšlenku, že:

přístup k učení není osobnostní charakteristikou studujících - nelze tedy mluvit o ,povrchových studujících a ,hloubkových studujících. Naopak, studující přistupují ke konkrétnímu studijnímu úkolu hloubkově nebo povrchově, podle toho, jak vnímají vzdělávací prostředí, v němž se tento úkol odehrává." (Pabian, 2012, s. 48)

Učení tedy není determinováno pouze osobnostními předpoklady, ale závisí především na tom, jak studující k učení přistupují. Pojetí učení zahrnuje osobní názor na učení samotné, jímž se student řídí. Zahrnuje otázky proč, kdy, kde, jak a z čeho se učit, jaké prožitky by měly učení provázet, podle čeho člověk pozná, že je naučen, jaký výsledek je přijatelný a jakou roli hraje prostředí učícího se (Mareš, 1998).

Pro usnadnění fenomenografického rozboru zkušenosti učení byly vytvořeny koncepční rámce co/jak a referenční/strukturální rámce (angl. what/how; referential/structural), které znázorňují jednotlivé prvky zkušenosti učení. Rámce vycházejí z výzkumu Pramlingové (1983, cit. podle Harris, 2011), která sledovala dětské pojetí učení a jejíž práce bývá považována za první oficiální fenomenografický výzkum využívající tyto rámce.

Koncepci si můžeme představit jako hierarchii, na jejímž vrcholu je samotný jev - zkušenost učení. Ta se dále rozděluje na rámce co/jak, které se člení na referenční a strukturální aspekty. Strukturální rámce jsou poté děleny na vnější a vnitřní horizont ${ }^{3}$ (srov. Marton \& Pong, 2005). Zaměřme se podrobněji na vysvětlení jednotlivých částí této struktury.

Aspekt co lze popsat jako obsah učení, jde o přímý objekt zkušenosti. $\mathrm{V}$ rámci tohoto aspektu sledujeme, na jaký obsah je zaměřena pozornost. Aspekt jak popisuje utváření porozumění, je orientován na samotný proces (Larsson \& Holmström, 2007). Tyto rámce se vnitřně strukturují na referenční/strukturální. Referenční (neboli významové) aspekty jsou jednotkami

3 Grafické znázornění této struktury viz Marton a Boothová (1997). 
popisu zkušenosti. Strukturální aspekty zahrnují vzájemné vztahy mezi stavebními prvky zkušenosti a zároveň vztahy jednotlivých částí k celku a naopak vztah celku k jednotlivým částem. Strukturální aspekt se dále skládá z vnějšího a vnitřního horizontu. Vnější odkazuje na pozadí dané zkušenosti, vnitřní na to, co je tematizováno v centru pozornosti (Yates et al., 2012). Způsob prožívání závisí na tom, jak jsou části jevu rozlišeny ve vědomí studenta. Ve stejné chvíli jsou určité části zaostřeny na popředí (tj. téma) a další přesunuty do pozadí (tj. tematické pole; Ornek, 2008). Marton a Boothová (1997) dokreslují toto členění následujícím příkladem. Jsme v temném lese a mezi stromy a keři stojí vysoká zvěř. Chceme-li spatřit její obrys, musíme ji rozeznat od temného pozadí. Podmínkou je, že musíme vědět, co chceme zaostřit, neboli přiřadit význam tomu, co chceme vidět, a odlišit objekt od kontextu. Bez záměru a následného odlišení od kontextu vysokou zvěř neuvidíme.

Tyto rámce mohou při analýze pomoci výzkumníkovi hlouběji porozumět procesu učení a vzájemným souvislostem. Rámce co/jak umožňují analyzovat data nejen z pohledu toho, jak je učení chápáno ve výsledku, ale také jak probíhá tento proces učení a jaké jsou motivy a cesty vedoucí k porozumění. Referenční a strukturální rámce umožňují kontextualizovat pojetí učení respondentů a rozebrat jednotlivé díly, z nichž se skládá. Jak podotkl Wilson (1977, cit. podle Mareš, 1998, s. 87), „badatelé nemohou porozumět lidskému chování, aniž porozumí vztahovému rámci, v němž jedinec interpretuje své uvažování, své pocity, své jednání. Tradiční výzkumné metody jsou neadekvátní, nebot' postrádají informace o tom, co sám aktér bere v úvahu“. Je důležité mít na paměti i omezení těchto rámců; učení je velmi relační, dynamický a složitý proces a je málo pravděpodobné, že tento způsob analýzy umožní rozkrýt všechny souvislosti (Harris, 2011).

\section{Vztah fenomenografie a fenomenologie - příčinná souvislost?}

Marton (1986) ve své snaze ukotvit základy výzkumu lidské zkušenosti dospěl k závěru, že je nutné přesáhnout původní podobu fenomenologie, jak ji formuloval Husserl (srov. Hendl, 2005). Fenomenografie má určité společné prvky s fenomenologií, v mnohém se ale odlišuje. Oba př́ístupy zajímá lidská zkušenost a prožívání světa. Zatímco fenomenologie se snaží o odhalení „základních esencí myšlení zbaveného nekonzistencí vnímání" (srov Hendl, 2005, s. 75), fenomenografie je zaměřena na variace prožívání různých jevů. 
Fenomenografie s příponou -graf (popis) symbolizuje výzkum zaměřený na popis různých způsobů porozumění fenoménu, zatímco fenomenologie s př́iponou -logos (slovo či smysl) se zaměřuje na objasnění struktury a významu fenoménu (Larsson \& Holmström, 2007). Ve srování s fenomenologií není fenomenografie tolik známý a běžný výzkumný přístup. Přitom ji někteří výzkumníci (srov. Larsson \& Holmström, 2007) považují za posun v kvalitativním výzkumu, a to především díky využitelnosti výsledků pro pedagogickou intervenci v konkrétních učebních situacích. Zároveň upozorňují, že jedna koncepce nemůže nahradit druhou, každá má své odlišné zaměření, cíle a výsledky.

Zatímco fenomenologie se zajímá o perspektivu prvního řádu, v níž se snaží o zachycení světa takového, jaký je, fenomenografie se soustředí především na pohled druhého řádu, tedy zachycení světa takového, jaký se jeví (Barnard, McCosker, \& Gerber, 1999). Jinými slovy, cílem fenomenologického kvalitativního výzkumu je zachycení podstaty daného jevu optikou aktérů, cílem fenomenografie není zachytit přímo fenomén jako takový, ale postihnout různé způsoby jeho prožívání (srov. Larsson \& Holmström, 2007). „Fenomenografie se zaměřuje na různé prožívání fenoménu, způsoby pohledu na něj, porozumění a získávání dovedností s ním spojených" (Marton \& Booth, 1997, s. 117). Smyslem fenomenologie je odhalit podstatu fenoménu, jeho vnitřní jádro, popsat, co ho utváří (Larsson \& Holmström, 2007). ${ }^{4}$

Dalším zásadním rozdílem jsou analytické výstupy. Fenomenologie se snaží o zachycení významových jednotek (angl. meaning units), kdežto výsledkem fenomenografické analýzy jsou kategorie popisu (angl. categories of description) a následný výsledný prostor (angl. outcome space), který se snaží o zobecnění individuální zkušenosti do „kolektivního smyslu“ (Barnard et al., 1999). Kategorie popisu jsou klíčovým prvkem fenomenografického výzkumu, jde o strukturovaný výsledek analýzy dat.

Oba postupy jsou zaměřeny na žitý svět aktérů výzkumu a snaží se o zachycení fenoménů $\mathrm{v}$ podobě, $\mathrm{v}$ jaké se lidem jeví. Zatímco fenomenologie zkoumá jev sám o sobě, fenomenografie sleduje, jak jej lidé chápou a jak mu rozumí. Ve fenomenologii hledáme podstatu, esenci jevu. Fenomenografie naopak hledá varianty způsobů jeho chápání (Larsson \& Holmström, 2007).

Larsson a Holmström (2007) se ve své studii věnují srovnání obou koncepcí na příkladu výzkumu práce anesteziologů. Zjednodušeně řečeno, fenomenologický výzkum zkoumá podstatu toho, co to znamená být anesteziolog, fenomenografický přístup zkoumá pojetí a porozumění smyslu práce anesteziologa. 


\section{$4 \quad$ Specifika fenomenografie ve vztahu k zakotvené teorii}

Fenomenografie představuje výzkum se specifickým sběrem dat a jejich analýzou. V mnohém se neliší od jiných kvalitativních výzkumných postupů. Podobný prrístup ke sběru dat a jejich analýze má především se zakotvenou teorií (srov. Strauss \& Corbin, 1999). Oba výzkumné přístupy jsou na první pohled podobné. Jejich rozdílnost je však zásadní už od samotného počátku, tedy od fáze stanovení výzkumného problému a formulování výzkumné otázky. Zakotvená teorie se soustředí na výzkum ústředního jevu, který bývá i ve výsledném modelu po selektivním kódování postaven jako ústřední kategorie nové teorie. Zakotvená teorie umožňuje sledovat interaktivní podstatu jevů, kde je každý jev vyjádřen pomocí vzájemně vztažených sekvencí (Strauss \& Corbin, 1999).

Fenomenografie se soustředí spíše na způsob prožívání daného jevu ve vědomí člověka. Výsledný prostor zobrazuje prožívání zkušenosti pomocí vzájemně spojených kategorií.

Oba designy mají společný induktivní př́istup k analýze dat a obdobné analytické postupy. Zakotvená teorie pracuje při analýze dat s daným paradigmatem - podmínečné vlivy, kontext, strategie, následky (srov. Strauss \& Corbin, 1999). Fenomenografie využívá základní rámce, jež jsou vodítkem při analýze dat (srov. Kinnunen \& Simon, 2012). Výsledkem zakotvené teorie je nová teorie usazená $v$ datech, výsledkem fenomenografického výzkumu je výsledný prostor zobrazující hierarchické vztahy mezi kategoriemi.

Základní metodou sběru dat ve fenomenografickém výzkumu je hloubkový rozhovor. ${ }^{5}$ Požadavky na způsob provedení jsou obdobné v obou přístupech. Fenomenografický rozhovor tematizuje aspekty zkušenosti a prožívání učení, přičemž se snaží o vyvolání hlubokých myšlenek respondenta, aniž by k tomu tazatel přímo respondenta vyzýval a naváděl (Yates et al., 2012). Rozhovor by neměl mít př́liš mnoho detailně připravených otázek, většina vyplývá přímo z rozhovoru s respondentem. ${ }^{6}$

5 Charakter sběru dat a následné analýzy se může lišit v závislosti na cíli výzkumu, obecně je hlavním nástrojem sběru dat rozhovor. Lze využít i analýzu písemných produktů, focus group, výkresy atp. (srov. Ornek, 2008).

6 Otázky mohou směřovat přímo k hlavnímu fenoménu: „Jak vlastně chápete pojem učení?“ Nebo se lze ptát na příklady: „Můžete mi říci, co jste se naučil?“ (Marton, 1994, cit. podle Cousin, 2009, s. 193). 
Základním analytickým procesem zakotvené teorie je kódování, jehož výstupem jsou kategorie. Ty představují proměnné neboli základní kameny budoucí teorie. Analytický proces je zaměřen na konstruování teorie pomocí paradigmatického modelu, tedy uvádění kategorií do vzájemných vztahů (Švaříček \& Šed'ová, et al., 2007).

Analýza fenomenografického výzkumu může být provedena různými způsoby. Prvním krokem je identifikace relevantních dat (angl. pool of meaning) $\mathrm{v}$ datovém korpusu. Následuje rozčlenění dat podle podobnosti, jejich kontrastování a vytváření prvních výstupů (Yates et al., 2012). Základem analýzy je rozlišení strukturálních a referenčních aspektů daného fenoménu. Při analýze sledujeme zároveň aspekty co/jak, tedy na co se subjekt výzkumu zaměřuje a zároveň jak danou zkušenost prožívá a jakým způsobem utváří porozumění. Bowden a Walsh (1994, cit. podle Åkerlind, 2005) identifikovali v analytických př́stupech různých výzkumníků následující ohniska zájmu: zaměření se na referenční (významové) nebo strukturální složky kategorií popisu; zaměření na co/jak aspekty jevu; zaměření se na podobnosti a rozdíly uvnitř a mezi kategoriemi; řešení neshod nebo nesouladu mezi různými výklady; zaměření se na hraniční přepisy a aspekty, které neodpovídají navrhované kategorii popisu; hledání důsledků změny pro celkovou strukturu a celek.

Závěrečným výstupem zakotvené teorie je návrh teorie, který vyslovuje výroky o vztazích mezi kategoriemi v různých kontextech (Strauss \& Corbin, 1999, s. 99). Výstupem fenomenografie jsou kategorie popisu, které zachycují jednotlivé dimenze zkoumaného fenoménu. Každá kategorie by měla být v jasném vztahu k danému fenoménu, zároveň musí jednotlivé kategorie stát v logickém vztahu k sobě navzájem (Marton, 1981, s. 125). Tato sada vzájemně propojených kategorií je následně sestavena do výsledného prostoru (Cousin, 2009, s. 185). Výsledný prostor je logicky strukturovaný komplex zobrazující různé způsoby prožívání zkušenosti daného fenoménu a zároveň reprezentuje fenomén samotný (Yates et al., 2012).

V zakotvené teorii ve finále hodnotíme, nakolik závěry výzkumu vycházejí z empirie. Provádíme tzv. empirické zakotvení závěrů, kdy posuzujeme jednotlivé pojmy, jejich systematické uvedení do vzájemných vztahů, pojmovou hutnost, celkovou variabilitu, zohlednění širších podmiňujících vlivů a identifikaci změn ve formě procesu (Strauss \& Corbin, 1999). Ve fenomenografii ověřujeme výstupy výsledků. 
Marton a Boothová (1997) stanovili tři základní kritéria pro posuzování kvality výsledků: Každá kategorie ve výsledném prostoru odhaluje něco výrazného ve způsobu chápání jevu, kategorie spolu logicky souvisejí a výsledky jsou dostatečně zhuštěné, kritické rozdíly pozorované v datech jsou zastoupeny několika kategoriemi.

Oba designy mají pro pedagogický výzkum svůj význam. Přes všechny odlišnosti o nich uvažují někteří výzkumníci jako o integrovaných přístupech (srov. Richardson, 1999). Každý z nich však představuje svébytný výzkumný přístup a volba mezi nimi by měla vždy vycházet $\mathrm{z}$ výzkumné otázky a cílů výzkumu. Metody si nekonkurují, každá přináší výsledky ze svého úhlu pohledu a jedna nemůže nahradit druhou.

\section{$5 \quad$ Př́klady fenomenografického výzkumu využití digitálních technologií ve vzdělávání}

Analýza realizovaných výzkumů od roku 2005 (Moyle, Wijngaards, \& Owen, 2012) ukázala, že dochází k nárůstu počtu studií věnovaných digitálním technologiím ve vzdělávání, pouze málo $\mathrm{z}$ nich je ale zaměřeno na samotné studenty a změny způsobů učení. Fenomenografie a její schopnost zachytit subjektivní stránku učení je zvláště významná pro výzkum využívání digitálních technologií v učení studentů (srov. Goodyear, 2008).

Jedním z prvních fenomenografických výzkumů týkajících se digitálních technologií ve vzdělávání byla disertační práce Boothové, která sledovala, jak se studenti učí programovat a jaké je jejich pojetí učení se programování (Booth, 1992, s. 69). Př́́kladem současného fenomenografického výzkumu digitálních technologií ve vzdělávání jsou práce australských výzkumníků (Ellis et al., 2011). Autoři se věnují učení vysokoškolských studentů s využitím internetu. $V$ tomto výzkumu se zaměřili na způsoby utváření zkušeností $\mathrm{s}$ učením prostřednictvím výzkumu na internetu. Sledovali, jak studenti přistupují k přijímání různých zdrojů informací a jaká rozdílná pojetí a přístupy zaujímají k jednotlivým úkolům. Autoři dokládají, že pojetí učení a přístupy studentů nejsou statické (ve smyslu stálých vlastností žáka), ale jsou odpovědí na konkrétní učební situaci (Ellis et al., 2011, s. 147). ${ }^{7}$

7 V dřívějším výzkumu se věnovali např. učení studentů prostřednictvím online a face-to-face diskusí (srov. Ellis et al., 2006). 
Fenomenografický teoreticko-metodologický přístup využila autorka i ve vlastním výzkumném šetření ${ }^{8}$, které se soustředí na způsoby využívání a subjektivní vnímání učení s využitím digitálních technologií optikou studentů Filozofické fakulty Masarykovy univerzity v Brně. Na př́íkladu autorčina výzkumu se zaměřme na konkrétní aplikaci fenomenografického př́istupu.

Fáze fenomenografického výzkumu jsou, obdobně jako u jiných kvalitativních přístupů, cirkulární a neprobíhají ve striktně lineárních krocích. Jednotlivé fáze mohou být realizovány paralelně, př́ípadně se výzkumník vrací a modifikuje předcházející kroky. Základní výzkumná otázka je výchozím prvkem a její zaměření určuje, zda je vůbec vhodné využít fenomenografický přístup. Otázka pro fenomenografický výzkum se nesoustředí přímo na daný jev, ale na způsoby jeho prožívání. $V$ uvedeném př́kladu se autorka neptá, jakou roli hrají digitální technologie při vysokoškolském studiu, ale jakým zpưsobem studenti využívají a vnímají digitální technologie ve studiu či procesu učení.

Předložené výsledky ${ }^{9}$ autorčina výzkumu vycházejí z analýzy devíti hloubkových rozhovorů, výzkumný vzorek nebyl dosud saturován. Fenomenografický rozhovor se soustředí na svět optikou respondenta $v$ jeho přirozeném světě. Specificky se zaměřuje na určitá témata a vodítkem jsou koncepční rámce, které znázorňují jednotlivé prvky učení (srov. Marton \& Booth, 1997). Autorka ve svém výzkumu účelově tematizovala oblasti týkající se zkušenosti učení s využitím digitálních technologií, zároveň ale podporovala proces uvažování respondenta, byla otevřena průběhu rozhovoru a dávala prostor k novým úvahám.

Rozhovory autorka přepsala a zahájila proces analýzy. V první fázi identifikovala relevantní data a rozčlenila je podle podobnosti. $\mathrm{K}$ hlubší analýze významu jednotlivých koncepcí využívá autorka rámce co/jak, zatímco referenční/strukturální rámce jí pomáhají k pochopení celkové struktury jednotlivých koncepcí. Tyto dva rámce jsou na sobě závislé, „struktura předpokládá význam a zároveň význam předpokládá struktury“ (Marton \& Booth, 1997, s. 87). Pomocí aspektů co/jak autorka odhaluje, které nástroje a v jakých situacích studenti využívají. Nejde pouze o zachycení konkrétních nástrojů, ale především jejich didaktických funkcí v konkrétních učebních situacích. V rámci referenčního aspektu autorka sleduje, jaký význam studenti připisují digitálním technologiím v konkrétních učebních situacích. Snaží se

8 Výzkum je součástí autorčina projektu disertační práce.

9 Jde o průběžné výsledky výzkumu, který je součástí autorčina projektu disertační práce. 
o pojmenování základních didaktických funkcí a toho, co se studenti s využitím digitálních technologií učí. Strukturální aspekty těchto didaktických funkcí umožňují autorce odhalit a popsat roli vnějších i vnitřních regulačních mechanismů, které ovlivňují způsoby nasazení.

Dílčí výsledky ve shodě s konceptem přístupů k učení rozlišují dva základní režimy využívání technologií (týká se pouze didaktické role „nosič obsahu“). V prvním případě je nasazení digitálních technologií charakteristické využíváním funkcí umožňujících rychlost a efektivitu. Tento způsob práce je určován především vnějším tlakem a studenti jej vnímají pouze jako nutný a nezbytný požadavek ke splnění. Práci s digitálním obsahem lze v tomto režimu charakterizovat jako vytváření koláže, při němž je základní množina informací vyhledaných především pomocí vyhledávače Google seskupena do nového celku. Vnitřní regulace, která je v souladu s individuálními preferencemi studentů, stimuluje překročení účelového povrchového přístupu a odpovídá charakteristikám hloubkového přístupu k učení. Práci s informacemi lze přirovnat v tomto režimu ke skládání mozaiky, kdy jsou do výchozího předpokladu tvořeného předchozími znalostmi doplňovány další poznatky a jsou dále rozvíjeny. Tento přistup ke studijním úkolům podněcuje širokou škálu způsobů využití digitálních technologií vedoucích k prohlubování vědomostí studentů (Staudková, 2015). ${ }^{10}$ Očekávaným výsledkem výzkumu je logická a hierarchická struktura zobrazená v tzv. výsledném prostoru. Identifikace dalších kategorií popisu a výsledný prostor výzkumu jsou předmětem další analýzy dat. ${ }^{11}$

Výsledný prostor fenomenografického výzkumu si můžeme ukázat na výzkumu Edwardsové a Bruceové (2006). Autorky využily fenomenografický př́istup při zkoumání zkušenosti studentů s vyhledáváním informací na webu. Výsledkem je pojmenování čtyř kategorií popisu (vyhledávání informací jako hledání jehly v kupce sena, cesta bludištěm, filtr, rýžování zlata), jež ústí ve výsledný prostor zobrazující hierarchické vztahy. Výsledný prostor znázorňuje kategorie rozmístěné na dvou stranách. ${ }^{12}$ Sloupec na levé straně zobrazuje kategorii studentů, kteři při vyhledávání informací nevnímají organizaci vyhledávacího prostředí, ačkoliv tuší existenci určité struktury a jsou si vědomi, že by jim mohla při vyhledávání pomoci (kategorie vyhledávání informací

10 Podrobnější výsledky výzkumu viz Staudková (2015).

11 Pro další ukázky fenomenografických výzkumů a výzkumných otázek týkajících se digitálních technologií ve vzdělávání odkažme na studie Harrise (2011, s. 118) a Kinnunena a Simona (2012, s. 203).

12 Grafické znázornění výsledného prostoru viz Edwardsová a Bruceová (2006). 
jako hledání jehly v kupce sena). Naopak sloupce na pravé straně představují způsoby vyhledávání, které respektují uspořádání a strukturu vyhledávacího prostředí. Sloupce tvoří tři zbývající kategorie (vyhledávání jako cesta bludištěm, filtrování a rýžování zlata), které jsou hierarchicky poskládány. Mezi levým a pravými sloupci je propast, která je způsobena zkušenostmi a (ne)respektováním principů uspořádání informací na webu a strategií jejich vyhledávání. Propast je přemostěna šipkou vyjadřující možnost jejího překonání, a to procvičováním a osvojením si těchto principů.

\section{Závěr}

Když v roce 1963 Needleman označil vztah fenomenografie k fenomenologii coby „bratra k ničemu“ (cit. podle Hasselgren \& Beach, 1997), jistě netušil, jakou významnou a produktivní výzkumnou školu založí švédští výzkumníci $\mathrm{v}$ čele s Ferencem Martonem o několik let později. Fenomenografie představuje samostatný výzkumný přístup, který v sobě integruje výzkum subjektivní zkušenosti vedený jasně definovanými postupy provádění a analytickými rámci. Výsledkem fenomenografických studií jsou obrazy způsobů myšlení, které mohou být užitečné pro pedagogickou teorii i praxi; mohou pomoci otevřít se novým postupům a prožívání zkušenosti.

Fenomenografické bádání má nezpochybnitelné úspěchy, zároveň $v$ sobě nese jistá omezení a je předmětem kritiky. Kritici této koncepci vyčítají, že byla vytvořena na základě výsledků výzkumů učení švédských badatelů kolem Ference Martona. Předmětem kritiky bývají i výsledné kategorie popisu a jejich redukce složitých jevů. Zobrazení výsledků jako hierarchicky uspořádaných kategorií však nemusí nutně vést k redukci významů, naopak výsledkem kvalitně provedeného fenomenografického výzkumu je jasně zobrazená (zhuštěná) anatomie složitého procesu proživání určitého jevu. Tyto výtky se mohou vztahovat i k dalším kvalitativním metodám a mohou přispět k teoreticko-metodologické diskusi o perspektivách kvalitativního přístupu obecně.

Cílem článku bylo především upozornit na možnosti fenomenografického přístupu a podnítit diskusi o možnostech jeho využití v českém pedagogickém výzkumu. Význam fenomenografie je klíčový pro oblast výzkumu vysokého školství, v níž má své kořeny a jíž je „šita na míru“. V českém prostředí je výzkum vzdělávání ve vysokém školství až překvapivě marginalizován (Pabian, 2012), výzkum digitálních technologií pak tvoří pouze zlomek těchto výzkumů. Proměny učení v současné digitální době jsou přitom stěžejní 
otázkou, jejíž zodpovězení může významně přispět k rozvoji a zajištění kvality výuky, tedy jedné ze současných priorit terciárního systému vzdělávání. Roli digitálních technologií nelze při výzkumu opomíjet, jde o hluboce zakořeněnou součást současného vysokého školství a ve shodě se Selwynem (2014) můžeme předpokládat, že bez náležité pozornosti tomuto důležitému prvku nelze plně vysokoškolskému vzdělávání porozumět.

\section{Poděkování}

Autorka děkuje recenzentům za připomínky, které významně přispěly ke zkvalitnění textu.

\section{Literatura}

Åkerlind G. S. (2005). Variation and commonality in phenomenographic research methods. Higher Education Research \& Development, 24(4), 321-334.

Barnard, A., McCosker, H., \& Gerber, R. (1999). Phenomenography: A qualitative research approach for exploring understanding in health care. Qualitative Health Research, 9, 212-226.

Booth, S. (1992). Learning to program: A phenomenographic perspective. Goteborg: Acta Universitatis Gothoburgensis.

Cousin, G. (2009). Researching learning in higher education. An introduction to contemporary methods and approaches. New York: Routledge.

Dahlin, B. (2007). Enriching the theoretical horizons of phenomenography, variation theory and learning studies. Scandinavian Journal of Educational Research, 51(4), 327-346.

Edwards, S. L., \& Bruce, C. S. (2006). Panning for gold: Understanding students information searching experience. In C. S. Bruce (Ed.), Transforming IT education: Promoting a culture of excellence (s. 351-371). Santa Rosa: Informing Science Press.

Ellis, R. A., Goodyear, P., Prosser, M., \& O'Hara, A. (2006). How and what universtity students learn through online and face-to-face discussions: Conceptions, intentions a approaches. Journal of Computer Assisted Learning, 22(4), 244-256.

Ellis, R. A., Goodyear, P., Bliuc, A.-M., \& Ellis, M. (2011). High school students'experiences of learning through research on the Internet. Journal of Computer Assisted Learning, 27(6), 503-515.

Goodyear P. (2008). Flexible learning and the architecture of learning places. In J. M. Spector (Ed.), Handbook of research on educational communications and technology (s. 251-257). New York: Routledge.

Harris, L. R. (2011). Phenomenographic perspectives on the structure of conceptions: The origins, purposes, strengths, and limitations of the what/how and referential/structural frameworks. Educational Research Review, 6(2), 109-124.

Hasselgren, B., \& Beach, D. (1997). Phenomenography - a "good-for-nothing brother" of phenomenology? Outline of an analysis. Higher Education Research \& Development, 16(2), 191-202. 
Hendl, J. (2005). Kvalitativní výzkum: základní metody a aplikace. Praha: Portál.

Kinnunen, P., \& Simon B. (2012). Phenomenography and grounded theory as research methods in computing education research field. Computer Science Education, 22(2), 199-218.

Larsson, J., \& Holmström, I. (2007). Phenomenographic or phenomenological analysis: Does it matter? Examples from a study on anaesthesiologists' work. International Journal of Qualitative Studies on Health and Well-being, 2(1), 55-64.

Linder, C., \& Marshall, D. (2003). Reflection and phenomenography: Towards theroretical and educational development possibilities. Learning and Instruction, 13(3), 271-284.

Mareš, J. (1998). Styly učení žáků a studentů. Praha: Portál.

Marton, F. (1981). Phenomenography: Describing conceptions of the world around us. Instructional Science, 10(2), 177-200.

Marton, F. (1986). Phenomenography: A research approach investigating different understandings of reality. Journal of Thought, 21(3), 28-49.

Marton, F., \& Booth, S. (1997). Learning and awareness. Hillsdale: Lawrence Erlbaum.

Marton, F., Dall'Alba, G., \& Beaty, E. (1993). Conceptions of learning. International Journal of Educational Research, 19(3), 277-300.

Marton, F., \& Pong, W. Y. (2005). On the unit of description in phenomenography. Higher Education Research \& Development, 24(4), 335-348.

Moyle, K., Wijngaards, G., \& Owen, S. (2012). Student's views about learning with technologies: A literature review. In K. Moyle \& G. Wijngaards (Eds.), Student reactions to learning with technologies: Perceptions and outcomes (s. 1-22). Hershey: IGI Global.

Ornek, F. (2008). An overview of a theoretical framework of phenomenography in qualitative education research: An example from physics education research. Asia-Pacific Forum on Science Learning and Teaching, 9(2), Article 11. Dostupné z https://www.ied.edu.hk/ apfslt/v9_issue2/ornek/.

Pabian, P. (2012). Jak se učí na vysokých školách: výzkumný směr „přístupů k učení“. AULA, 1(1), 48-77.

Prosser, M., Trigwell, K., \& Taylor, P. (1994). A phenomenographic study of academics' conceptions of science learning and teaching. Learning and Instruction, 4(3), 217-231.

Richardson, J. T. E. (1999). The concept and methods of phenomenographic research. Review of Educational Research, 69(1), 53-82.

Selwyn, N. (2014). Digital technology and the contemporary university. New York: Routledge.

Staudková, H. (2015). Způsoby využívání digitálních technologií vysokoškolskými studenty. Pedagogika, 65(3), 301-313.

Strauss, A. L., \& Corbin, J. (1999). Základy kvalitativního výzkumu. Postupy a techniky metody zakotvené teorie. Boskovice: Albert.

Švaříček, R., Šed’ová, K., Janík, T., Kaščák, O., Miková, M., Nedbálková, K., ... Zounek, J. (2007). Kvalitativní výzkum v pedagogických vědách: pravidla hry. Praha: Portál.

Tight, M. (2015). Phenomenography: The development and application of an innovative research design in higher education research. International Journal of Social Research Metodology, 19(3), 1-20.

Vermunt, J. D. (1996). Metacognitive, cognitive and affective aspects of learning styles and strategies: A phenomenographic analysis. Higher Education, 31, 25-50.

Yates, C., Partidge, H., \& Bruce, C. S. (2012). Exploring information experiences through phenomenography. Library and Information Research, 36(112), 96-119. 


\title{
Autorka
}

Mgr. Hana Staudková, Masarykova univerzita, Filozofická fakulta, Ústav pedagogických věd, Arna Nováka 1, 60200 Brno, e-mail: hanna@mail.muni.cz

\section{Using phenomenographic approach: An example of research on digital technologies in education}

\begin{abstract}
This paper discusses the potentialities of employing phenomenography in educational research using an example of researching digital technologies in education. This research approach is rather unknown and underused in the Czech research environment; accordingly, the main goal of the paper is to open a discussion about applying phenomenography in Czech educational research. The first part focuses on roots and basic principles of this approach. The paper then opens questions about the relationship between phenomenography and phenomenology. They are presented as separate approaches, each with a different focus, objectives and results. Phenomenographic methodological procedures are confronted with the grounded theory design; the paper describes their basic differences and similarities. The possibilities of using phenomenographic approach are illustrated using examples of research related to utilizing digital technologies in education. Finally, advantages and disadvantages of phenomenography are discussed. It appears that this research approach has great and unexploited potential for Czech educational research and is especially suitable for higher education research.
\end{abstract}

Keywords: phenomenography, higher education research, digital technology in education

Lazarová, B., Hloušková, L., Trnková, K., Pol, M., Lukas, J. (2016). Řízení inkluze ve škole. Brno: MU.

Publikace se věnuje tématu řízení inkluzivního vzdělávání v českých školách. První část obsahuje analýzu mezinárodního a českého politického diskurzu týkajícího se realizace inkluze ve vzdělávání v posledních dvaceti letech. Druhá část publikace se pak zaměřuje na témata spojená $s$ ř́ízením inkluzivního vzdělávání a ústí $\mathrm{v}$ analýzu výsledků vícečetné případové studie řízení inkluzivního vzdělávání v českých základních školách. 